\title{
STANOWISKO PIERWSZYCH BRYTYJSKICH EMERGENTYSTÓW WOBEC TEORII EWOLUCJI
}

Współcześnie mówi się o wielkim powrocie koncepcji emergencji. Pojawia się ona nie tylko w ramach nauk filozoficznych, ale jest szeroko obecna w naukach przyrodniczych i społecznych ${ }^{1}$. Jednym z założeń zachodzenia zjawisk emergentnych jest uwzględnienie procesu ewolucji. Jednakże u początków formowania się nurtu emergentyzmu, to połączenie emergencji z procesem ewolucji dopiero następowało. Teoria ewolucji nie była jeszcze powszechnie przyjmowana i dopiero upowszechniała się w środowisku naukowym, a tym samym i u brytyjskich emergentystów.

Celem tego artykułu jest ukazanie odmiennego podejścia do teorii ewolucji Johna Stuarta Milla (1806-1873) oraz George'a Henry'ego Lewesa (1817-1878). W artykułach naukowych nawiązujących do brytyjskiego emergentyzmu zawsze wymieniani są oni na pierwszym miejscu. Mill uważany jest za ojca tego kierunku, a Lewesowi zawdzięcza się wprowadzenie pojęcia emergencji na określenie skutku nie będącego wypadkową swoich części.

Początków idei emergencji można poszukiwać, jak wspomina w swoim artykule John Haldane, już w starożytności u presokratyków². Jednak już Arystoteles w swoich badaniach dotyczących metafizyki zwrócił uwagę, że całość jest czymś więcej, niż tylko sumą części składowych. Kolejni filozofowie poruszali tę myśl, jednak dopiero brytyjscy emergentyści podjęli systematyczne badania. Brian P. McLaughlin i Achim Stephan, zajmujący się historią tego nurtu, wymieniają pięć zasadniczych prac napisanych przez jego głównych przedstawicieli: „System of Logic” (1843) Johna Stuarta Milla, „Problems of Life and Mind” (1875) George'a Henryego Lewesa, ,Space, Time, and Deity” (1920) Samuela Alexandra (1859-1938), „Emergent Evolution” (1923) Conwy'ego Lloyda Morgana (1852-1936) i ,, The Mind and

1 Przyczynę tego nawrotu wiąże się z wynikami współczesnych badań matematycznych nad układami nieliniowymi, teorią chaosu oraz teorią złożoności. Teorie te, pozwoliły w skuteczny sposób opisać i rozwiązać wiele problematycznych kwestii wywodzących się ze wspomnianych nauk. Szerzej o wpływie wymienionych metod matematycznych na różne nauki zob. K. Meizner, Poznawanie złożoności. Obliczeniowa dynamika materii, umystu i ludzkości, tłum. M. Hetmański, Lublin 2007.

2 J. Haldane, The Mystery of Emergence, „Proceedings of the Aristotelian Society” 96 (1996), s. 261. 
Its Place in Nature" (1925) Charliego Dunbara Broada (1887-1971)³. McLaughlin, analizując powstanie jak i upadek brytyjskiego emergentyzmu, przedstawia wyidealizowaną wersję jego korpusu, w dużym stopniu pomijając niezgodności występujące między emergentystami. Wymienia cztery wspólne cechy emergentyzmu. Po pierwsze, dla brytyjskiego emergentyzmu świat składa się tylko z materii, rozumianej nie jako coś ciągłego, ale coś ziarnistego. Wszystkie obiekty składają się z takiej materii, a ona podlega prawom mechaniki. Wyklucza to istnienie świata duchowego, czy elementów sił witalnych. Po drugie, w tym świecie wyróżnia się hierarchiczne poziomy organizacji: poziom fizyczny, chemiczny, biologiczny, psychiczny. Każdy kolejny poziom powstaje na bazie poprzedniego. Po trzecie, na kolejnych poziomach emergują moce przyczynowe. Po czwarte, w przypadku mocy przyczynowych wiążą się one także z tzw. przyczynowością odgórną ${ }^{4}$. Owe cechy zostały wyliczone, aby zwrócić uwagę na jeszcze jedną cechę wyróżniającą wszystkich wymienionych emergentystów, prócz Milla. Cecha ta dotyczy uwzględnienia teorii ewolucji. Ideę emergencji z ewolucją biologiczną starali się łączyć Alexander, Morgan i Broad. Pisze o tym Reuben Ablowitz ${ }^{5}$. Natomiast David Blitz, z powyższych wymienionych prac emergentystów, pokreśla zwłaszcza znaczenie publikacji Morgana dla odpowiedniego zrozumienia teorii ewolucji w kategoriach emergentyzmu ${ }^{6}$. Myśl ewolucyjna obecna jest także w badaniach Lewesa.

Dla lepszego zobrazowania stanowiska Milla i Lewesa wobec teorii ewolucji warto przybliżyć jej początki, które czasowo pokrywają się z rozwojem brytyjskiego emergentyzmu. Sama myśl o zachodzących procesach ewolucji była obecna w kulturze Europy Zachodniej jeszcze przed narodzinami Milla, Lewesa, oraz samego Darwina7. W 1859 r. Karol Darwin wydał książkę ,, On the Origin of Species ”. Dzieło to było znaczące, jak zaznacza Armand A. Maurer, ze względu na toczący się w owym czasie spór o koncepcję filozofii naturalnej sformułowanej przez Johna Raya (1627-1705). Ray, angielski przyrodnik i teolog twierdził, że ilość gatunków w przyrodzie jest ustalona, ograniczona, stała i niezmienna od chwili stworzenia świata przez Boga. Uważał to za wniosek naukowy, powszechną opinię filozofów oraz za pogląd zgodny z doktryną Pisma Świętego. Zatem, w jego przekonaniu, przyrodnicy nie muszą zastanawiać się nad pochodzeniem gatunków, tylko je opi-

3 B. P. McLaughlin, The Rise and Fall of British Emergentism, w: Emergence or Reduction? Essays on the Prospects of Nonreductive Physicalism, Berlin 1992, s. 49; A. Stephan, Emergence - A Systematic View on its Historical Facets, w: Emergence or Reduction? Essays on the Prospects of Nonreductive Physicalism, Berlin 1992, s. 25. B. P. McLaughlin, The Rise and Fall..., dz. cyt., s. 49-51.

5 Zob. R. Ablowitz, The theory of emergence, „Philosophy of Science” 6 (1939), z. 1.

6 Zob. D. Blitz, Emergent evolution: Qualitative novelty and the levels of reality, Dordrecht 1992.

7 Szerzej o obecności idei ewolucji w kulturze przed Darwinem i po nim zob.: D. Oramus, Darwinowskie paradygmaty. Mit teorii ewolucji w kulturze wspótczesnej, Kraków 2015, s. 113-126. 
sywać i klasyfikować. Ową koncepcję niezmienności gatunków potwierdził także w swoich badaniach Karol Linneusz (1707-1778), ale uwzględnił w nich dane empiryczne związane z rozmnażaniem gatunków hybrydowych. Według niego pogląd ten nie odnosił się do świata roślin, gdyż w tym obszarze (w tej dziedzinie) powstawanie nowych gatunków było jednak możliwe. Ze względu na to ustępstwo Georges Luis Leclerc, znany powszechnie jako Hrabia de Buffon (1707-1788), zakwestionował dodatkowo niezmienność gatunków zwierząt, bowiem nie dostrzegał żadnych absolutnych granic między gatunkami oraz między królestwem zwierząt i roślin. Pod koniec XVIII w. idea ewolucji organicznej zdobyła już popularność i była umacniana coraz to nowymi danymi naukowymi. Erasmus Darwin (1731-1802) podał uwagi odnośnie do organów zwierzęcych kształtowanych ze względu na ich użyteczność w środowisku. Jean Baptiste Lamarck (1744-1829) pisał o życiu przybierającym formy o większej złożoności i wznoszącym się na wyższe poziomy. Początkowo także Karol Darwin pozostawał pod wpływem poglądu o niezmienności gatunków. Dopiero na pokładzie „Beagle”, w czasie wyprawy naukowej jego wizja świata zmieniła się. Wydana później książka zawierała dużą ilość danych z przeprowadzonych przez niego obserwacji, które w jego przekonaniu były argumentami na poparcie ewolucji. Dane te, przekonały wielu ludzi nauki. Zainteresowanie teorią K. Darwina powoli rozwijało się i prowadziło do licznych dyskusji. Próbowano ją także włączać w rozważania filozoficzne ${ }^{8}$.

Maur wskazuje, że pierwszym angielskim filozofem, który wykorzystał systematycznie idee ewolucyjne był Herbert Spencer (1820-1903). Znał on osobiście Milla oraz Lewesa i interesował się literaturą ewolucjonistyczną. Zanim pojawiła się teoria K. Darwina, Spencer był po wpływem Jean-Baptiste’a de Lamarcka, według którego ewolucja organizmów dokonuje się poprzez przystosowanie do środowiska i przekazywanie zmian własnych struktur potomstwu, Friedricha Wilhelma Josepha von Schellinga, twierdzącgo że ewolucja życia polega na ciągłym rosnącym zróżnicowaniu, organizacji i indywidualizacji, oraz Karla Ernsta von Baera, wskazującego iż organizm rozwija się przechodząc od stanu jednorodności do różnorodności i Thomasa Roberta Malthusa, który opracował teorię demograficzną. Spencera jednak nie tyle interesowała ewolucja jako naukowa hipoteza przyrodnicza, ale bardziej jako filozoficzne prawo ewolucji, które obejmowałoby świat organiczny oraz nieorganiczny. Chciał on stworzyć filozofię ewolucji. Miało to związek z jego koncepcją wiedzy. Jego zdaniem postęp wiedzy polega na jej coraz większym uogólnianiu i ujednolicaniu. Najniższym rodzajem wiedzy jest wiedza o jednostkowych faktach. Nauka jest już wiedzą częściowo zunifikowaną, natomiast filozofia jest wiedzą całkowicie zunifikowaną. Filozofia łączyła fakty wykryte przez nauki szczegółowe, co pozwoliło jej formułować pierwsze zasady rządzące rozwojem całego Wszechświata. Wobec powyższego Spencer szukał owych pierwszych zasad. Na podstawie

8 A. A. Maurer, Rozdziat XVII. Filozofia ewolucji, przeł. B. Chwedeńczuk, w: Historia Filozofii Współczesnej, red. E. Gilson, T. Langan, A. A. Maurer, Warszawa 1977, s. 393-395. 
analizy poglądów wymienionych wcześniej autorów, sformułował prawo ewolucji, które można wydedukować z zasady filozoficznej, nazwanej przez niego ,zasadą zachowania siły". Jest ona najbardziej ogólną prawdą, implikuje każde doświadczenie oraz jest nie do udowodnienia. Wszechświat zaś nieustannie przechodzi od równowagi do rozkładu oraz od rozkładu do równowagi ${ }^{9}$. Filozofia ewolucji Spencera wywołała odzew ludzi nauki. Pojawili się oczywiście krytycy. W Ameryce jego filozofię krytykowali pragmatyści amerykańscy: Chauncey Wright, Ch. S. Peirce, William James. Najpotężniejszy atak nastąpił w Anglii, za sprawą filozofa Henriego Bergsona. Ewolucjonizm Spencera znalazł jednak podatny grunt, zarówno w Ameryce, jak i w Anglii. Stanowił on między innymi inspirację dla przedstawicieli brytyjskiego emergentyzmu: Morgana i Alexandera ${ }^{10}$. Do listy zwolenników tych poglądów należy dodać także Lewesa. Natomiast stanowisko Milla wobec teorii ewolucji jest bardziej skomplikowane.

Mill znany jest przede wszystkim ze swoich poglądów politycznych i ekonomicznych. Spośród jego prac wyróżnia się przede wszystkim: „, A System of Logic” (1843), ,The Principles of Political Economy” (1848) oraz „On Liberty” (1859). $\mathrm{W}$ pierwszej z wymienionych, przedstawione są rozważania związane z ideą emergentyzmu. To właśnie dzięki nim Mill uważany jest, jak twierdzi McLaughlin, za ojca brytyjskiego emergentzymu. Mill napisał o tzw. homopatycznych oraz heteropatycznych skutkach i prawach. Zastosował Zasadę Składania Sił, poprzez wektory, do kwestii przyczynowo-skutkowej. Gdy przyczyny działają wzajemnie powodując pewien typ skutku będący sumą wektorową lub algebraiczną tych typów skutków owych przyczyn, to nazywamy je skutkiem homopatycznym. Prawa stwierdzające tę przyczynowo-skutkową relację nazwał on prawami homopatycznymi. Gdy natomiast przyczyny działają wzajemnie powodując pewien typ skutku nie będący sumą wektorową lub algebraiczną tych typów skutków owych przyczyn, to nazywamy je skutkiem heteropatycznym. Prawa opisujące tę przyczynowo-skutkową relację nazwał heteropatycznymi prawami. Istnienie zjawisk homopatycznych dostrzegał on w fizyce, natomiast heteropatycznych w chemii. Zmiana właściwości fizykochemicznych podczas reakcji wodoru z tlenem, w wyniku której powstaje woda, jest przykładem, który często przytaczali za Millem późniejsi naukowcy. Ów podział składania przyczyn tłumaczył także istnienie różnych nauk i niesprowadzalność ich do fizyki ${ }^{11}$. W tym zawierającym ideę emergenztymu dziele z $1843 \mathrm{r}$., podobnie jak w dwóch wymienionych powyżej pracach, brak jest jednak odniesienia do myśli ewolucjonistycznej. Bruce Mazlish stwierdził, że rewolucja związana z teorią ewolucji ominęła Milla, gdyż swoje główne dzieła wydał on przed pojawieniem się publikacji Darwina. Według niego Mill był jednak świadomy pracy, jakiej dokonał Darwin. Wskazują na to jego własne słowa, jak i historia jego życia. W liście do Alexandra Baina z 11 maja 1860 r. napisał:

\footnotetext{
9 A. A. Maurer, Rozdziat XVII..., dz. cyt., s. 398-400.

10 A. A. Maurer, Rozdziat XVII..., dz. cyt., s. 404-405.

11 B. P. McLaughlin, The Rise and Fall..., dz. cyt., s. 58-63.
} 
„Wspomniałem w moim ostatnim liście, że ukończyłem pierwszy szkic mojej nowej książki. Od mojego powrotu tutaj, przeczytałem kilka interesujących mnie rzeczy, przede wszystkim książkę Darwina. Znacznie przekracza ona moje oczekiwania. Chociaż nie można powiedzieć, że udowodnił on prawdziwość swojej doktryny to wydaje się, że udowodnił, iż może ona być prawdziwa, co uważam za największy możliwy triumf, jaki wiedza i pomysłowość mogą w ogóle osiągnąć w kwestii takiego pytania. Z pewnością nic nie może być, na pierwszy rzut oka, bardziej niewiarygodne niż jego teoria; jednak rozpocząwszy od przekonania o jej niemożliwości, dochodzi się to swojego rodzaju rzeczywistej wiary w tę teorię, uniemożliwiającej powrót do niedowierzania"'12.

Zaś w piątej edycji „A System of Logic” z 1862 r. znajduje się przypis o następującej treści:

„Niezwykłe rozważania pana Darwina na temat Pochodzenia Gatunków są kolejnym nie dającym się zakwestionwać przykładem zasadnej hipotezy. To, co nazywa «doborem naturalnym» stanowi nie tylko vera causa, ale ponadto udowodniono, że jest on w stanie wytworzyć skutki tego samego rozdaju co przypisywane przez hipotezę. Nieuzasadnione jest oskarżanie pana Darwina (jak to zrobiono) o naruszenie zasad indukcji: pytanie o możliwość jest w całości pytaniem o stopień. (...) Zasady indukcji dotyczą warunków dowodu. Pan Darwin nigdy nie twierdził, że jego doktryna została udowodniona. Nie był związany zasadami indukcji, ale hipotezy. A te ostatnie rzadko kiedy były spełnione w większym stopniu. Otwarł ścieżkę badawczą pełną obietnic, której wyników nikt nie jest w stanie przewidzieć. Czy nie jest to cudowny wyczyn wiedzy naukowej i pomysłowości, aby zaproponować tak śmiałą sugestię, wobec której pierwszym odruchem każdego było odrzucenie, aprobata i polemika z nią, traktowaną nawet jako przypuszczenie"13.

12 J. S. Mill, The Collected Works of John Stuart Mill, Volume XV - The Later Letters of John Stuart Mill 1849-1873 Part II, ed. Francis E. Mineka and Dwight N. Lindley (Toronto: University of Toronto Press, London: Routledge and Kegan Paul, 1972). http:// oll.libertyfund.org/titles/252\#Mill_0223-15_564 [dostęp: 24 III 2015 r.]. Tłum. własne. „I mentioned in my last letter that I had completed the first draft of the new book. I have read since my return here, several things which have interested me, above all Darwin's book. It far surpasses my expectation. Though he cannot be said to have proved the truth of his doctrine, he does seem to have proved that it may be true which I take to be as great a triumph as knowledge \& ingenuity could possibly achieve on such a question. Certainly nothing can be at first sight more entirely unplausible than his theory \& yet after beginning by thinking it impossible, one arrives at something like an actual belief in it, \& one certainly does not relapse into complete disbelief".

13 J. S. Mill, The Collected Works of John Stuart Mill, Volume VII - A System of Logic Ratiocinative and Inductive, Being a Connected View of the Principles of Evidence and the Methods of Scientific Investigation (Books I-III), ed. John M. Robson, Introduction by R. F. McRae (Toronto: University of Toronto Press, London: Routledge and Kegan Paul, 1974). http://oll.libertyfund.org/titles/246\#lf0223-07_label_3237. [dostęp: 24 III 2015 r.]. Tłum. własne. „Mr. Darwin’s remarkable speculation on the Origin of Species is another 
W podsumowaniu Mazlish stwierdza, że pomimo wielkiego wrażenia, jakie zrobiła na Millu teoria Darwina, nie podążył on jej śladami, nawet w naukach społecznych ${ }^{14}$. Odniósł się jednak do poglądów Darwina w związku z kwestią religijną, o czym można się dowiedzieć dzięki pośmiertnej publikacji „,Three Essays on Religion”, wydanej przez jego pasierbicę Helen Raylor w 1874 r.

W rozważaniach nad problemem badawczym niniejszego artykułu, należy odnieść się do biografii Milla i zwrócić uwagę na jego udział w spotkaniach salonowych londyńskiego wydawcy Johna Chapmana, w których brał udział. Odbywały się one w domu Chapmana i gromadziły dziennikarzy, pisarzy i myślicieli, którzy w przyszłości stali się sławnymi postaciami epoki wiktoriańskiej. Wśród nich byli m.in. Charles Dickens, wspominany już Herbert Spencer, propagator darwinizmu Thomas Henry Huxley, Mary Ann Evans i George Henry Lewes. W 1851 r. Chapman wykupił kwartalnik „Westminster Review”, w którym zaczęto promować darwinowski ewolucjonizm ${ }^{15}$. Ponadto Mill pozostawał w przyjaznych stosunkach ze Spencerem, korespondowali ze sobą, a Spencer co pewien czas bywał na kolacjach w domu Milla ${ }^{16}$. Przytoczone fakty świadczą o znajomości myśli ewolucjonistycznej przez Milla, choć trudno określić jej stopień. Nie wpłynęła ona jednak na koncepcje opracowywane przez Milla. To samo można jednak rzec o homopatycznych oraz heteropatycznych skutkach i prawach opisanych przez Milla w „, A System of Logic”. Raz opisane nie znajdują zastosowania w koncepcjach samego odkrywcy.

Z kolei w przypadku Lewesa, jego głównym wkładem do nurtu brytyjskiego emergentyzmu jest według McLaughlina, wprowadzenie terminu „emergentny”. McLaughlin stwierdził, że prace Lewesa zorientowane są na obronę brytyjskiego empiryzmu, a nie na nurt emergentyzmu ${ }^{17}$. Termin ten pojawia się $\mathrm{w}$ dziele Lewesa

unimpeachable example of a legitimate hypothesis. What he terms "natural selection" is not only a vera causa, but one proved to be capable of producing effects of the same kind with those which the hypothesis ascribes to it: the question of possibility is entirely one of degree. [See Charles Darwin. On the Origin of Species. London: Murray, 1859.] It is unreasonable to accuse Mr. Darwin (as has been done) of violating the rules of Induction. The rules of Induction are concerned with the conditions of Proof. Mr. Darwin has never pretended that his doctrine was proved. He was not bound by the rules of Induction, but by those of Hypothesis. And these last have seldom been more completely fulfilled. He has opened a path of inquiry full of promise, the results of which none can foresee. And is it not a wonderful feat of scientific knowledge and ingenuity to have rendered so bold a suggestion, which the first impulse of every one was to reject at once, admissible and discussable, even as a conjecture?"

14 B. Mazlish, James and John Staurt Mill. Father and Son in the Nineteenth Century, New York 1975, s. 424.

15 Szerzej o spotkaniach salonowych u Johna Chapmana zob.: R. Ashton, 142 Strand: A Radical Address in Victorian London, London 2006.

${ }^{16}$ H Spencer, Autobiography, t. 2, London 1904; N. Capaldi, John Stuart Mill. A Biography, New York 2004; H. G. Tjoa, George Henry Lewes: A Victorian Mind, Cambridge 1977.

17 B. P. McLaughlin, The Rise and Fall...., dz. cyt., s. 65. 
„Problems of Life and Mind". Nawiązując do skutków homopatycznych i heteropatycznych opisanych przez Milla, nazwał on skutek heteropatyczny emergentnym ${ }^{18}$. U Lewesa można odnaleźć coś na kształt definicji takich skutków, a także stwierdzenie o mnogości występowania takich skutków w świecie. Podobnie jak Mill, także Lewes wykorzystał m.in. przykład reakcji fizykochemicznych. Na tej podstawie dowodził niepewności dedukcji, która zawsze wymaga odwołania się do doświadczenia, aby zostać ostatecznie potwierdzoną ${ }^{19}$. Trudno jest zgodzić się z opinią McLaughlina, która umniejsza znaczenie poglądów Lewesa dla nurtu emergentyzmu. Prace Milla także nie rozwijały tematu emergencji. Według Stephana, pomimo podobieństw w koncepcjach emergentystycznych Milla i Lewesa związanych nieprzewidywalnością emergentnych skutków i używaniem tych samych przykładów, ich koncepcje się różnią. Zależność własności emergentnych od posiadanej wiedzy, świadczy o epistemologicznym rozumieniu emergencji przez Lewesa, niewystępującym u Milla ${ }^{20}$. Ponadto Lewes nie poprzestaje na przykładach Milla. Łączy emergencję z psychologią i socjologią. Najcześciej przywoływane fragmenty dotyczące tej kwestii pochodzą z badań nad psychologią znajdujących się w ,,Problems of Life and Mind" z 1879 r. Przywołany fragment ukazuje działanie emergencji w tworzeniu się Umysłu Powszechnego:

„Co więcej, doświadczenia każdego człowieka przychodzą i odchodzą; korygują się, powiększają, niszczą się nawzajem, zostawiając za sobą pewien szczątkowy zasób skumulowany w intuicjach i sformułowany w zasady, który kieruje i modyfikuje wszystkie przyszłe doświadczenia. Suma tych doświadczeń określana jest indywidualnym umysłem. Podobny proces kształtuje Powszechny Umysł - szczątkowy zasób doświadczeń dostępny dla wszystkich. Za pomocą języka każdy ma udział w ogólnym zasobie, który pełni rolę bezosobowego, obiektywnego czynnika wpływającego na nas. Każdy czerpie z ogólnego zasobu. Przyswajamy sobie część tego zasobu, a zarazem ubogacamy go. Stawiamy bowiem czoła Naturze, której musimy się podporządkować, ale i Społeczeństwu, którego praw musimy przestrzegać. Musimy nauczyć się, czym jest i jak działa Natura, co myślą i czego chcą nasi współbracia, gdyż dopóki nie czynimy tego właściwie podporządkowując się, jesteśmy nieubłagalnie karani”"21.

18 C. L. Morgan, Emergent Evolution, London 1923, s. 2-3.

19 G. H. Lewes, Problems of Life and Mind: First Series: The Foundations of a Creed, t. 2, Boston 1875, s. 368-370

20 A. Stephan, Emergence - A Systematic View on its Historical Facets, w: Emergence or Reduction? Essays on the Prospects of Nonreductive Physicalism, red. A. Beckermann, H. Flohr, J. Kim, Berlin 1992, s. 28-30.

${ }^{21}$ G. H. Lewes, Problems of Life and Mind: Third Series: The Study of Psychology, thum. własne, t. 1, London 1879, s. 161-162. „Further, the experiences of each individual come and go; they correct, enlarge, destroy one another, leaving behind them a certain residual store, which, condensed in intuitions and formulated in principles, direct and modify all future experiences. The sum of these is designated as the individual mind. A similar process 
Natomiast poniższy fragment dotyczy emergencji społecznych reguł życia:

„Drogi, targowiska i świątynie są dla każdego. Doświadczenia, dogmaty i doktryny są dla każdego. Zwyczaje powstają, są formułowane w prawa i ograniczają każdego. Zwyczaje zrodzone $\mathrm{z}$ okoliczności, tkwiące w warunkach społecznych są świadomie stamtąd wydobywane i określane jako reguły życia; każde nowe pokolenie rodzi się w tym medium społecznym i musi się zaadoptować do ustalonych form. Społeczeństwo, choć tworzone przez jednostki, ma silny na nie wpływ. «W okresie niemowlęctwa narodów», twierdzi Montesquieu, «ludzie kształtują państwo; w swojej dojrzałości państwo kształtuje ludzi». Jest to wspólne doświadczenie rasy kształtujące doświadczenie jednostki. Przyczynia się to do akceptacji przez człowieka czegoś czego nie może zrozumieć i być posłusznym temu, w co nie wierzy. Jego myśli są tylko częściowo własnymi; są także myślmi innych ${ }^{22}$ ".

Cały rodział dotyczący „,powszechnego umysłu”, z którego pochodzą zacytowane fragmenty, to połączenie myśli emergentystycznej z ewolucjonizmem. Umysł ludzki jest zależny od ciała, ale i od społeczeństwa, które emergowało na bazie indywidualnych umysłów. Natomist badania zawarte w tym tomie, jak zaznacza Scott C. Thompson, stanowią wielki wkład Lewesa w psychologię. Opierając się bowiem na biologii ewolucyjnej Spencera i socjologii Comte'a, dodał on niezbędny czynnik społeczny do badań nad umysłem i świadomością 23 . Diana Postelethwaite wymienia źródła przeddarwinowskie mające wpływ na wczesne rozumienie ewolucji przez Lewesa, którymi są: jedność kompozycji przedstawione przez Goethego, problematyka relacji organizmu i środowiska Comte'a oraz rozwój od jednorodności do różnorodności opisany przez Baera ${ }^{24}$.

evolves the General Mind - the residual store of experiences common to all. By means of Language the individual shares in the general fund, which thus becomes for him an impersonal objective influence. To it each appeals. We all assimilate some of its material, and help to increase its store. Not only do we find ourselves confronting Nature, to whose order we must conform, but confronting Society, whose laws we must obey. We have to learn what Nature is and does, what our fellow-men think and will, and unless we learn aright and act in conformity, we are inexorably punished".

22 G. H. Lewes, Problems..., dz. cyt., s. 164-165. „The roads, market-places and temples, are for each and all. The experiences, the dogmas, and the doctrines are for each and all. Customs arise, and are formulated in laws, the restraint of all. The customs, born of the circumstances, immanent in the social conditions, are consciously extricated and prescribed as the rules of life; each new generation is born in this social medium, and has to adapt itself to the established forms. Society, though constituted by individuals, has a powerful reaction on every individual. «In the infancy of nations», said Montesquieu, «man forms the state; in their maturity the state forms the man». It is thus also with the collective Experience of the race fashioning the Experience of the individual. It makes a man accept what he cannot understand, and obey what he does not believe. His thoughts are only partly his own; they are also the thoughts of others".

23 S. C. Thompson, „On G. H. Lewes's Problems of Life and Mind, 1874-1879”. BRANCH: Britain, Representation and Nineteenth-Century History. Ed. Dino Franco Felluga. Extension of Romanticism and Victorianism on the Net. Web. [dostęp: 19 III 2019 r.].

${ }^{24}$ D. Postlethwaite, Making It Whole. A Victorian Circle and the Shape of Their World, Columbus 1984, s. 192. 
Podsumowując należy podkreślić, że choć Lewes i Mill żyli w tym samym okresie i w tym samym intelektualnym środowisku, tylko Lewes wykorzystał w swoich badaniach zarówno koncepcje emergencji jak i ewolucji. Trudno te badania uznać za systematyczne, jednakże zarówno koncepcje emergencji i ewolucji przewijały się w jego rozważaniach psychologicznych i socjologicznych. Są one obecne w tych dziedzinach po dziś. Dla kolejnych brytyjskich emergentystów, Alexandra, Morgana i Broada, wzajemny związek tych koncepcji był już czymś oczywistym.

\section{BIBLIOGRAFIA}

\section{Źródla internetowe:}

Mill J. S., The Collected Works of John Stuart Mill, Volume XV - The Later Letters of John Stuart Mill 1849-1873 Part II, ed. Francis E. Mineka and Dwight N. Lindley (Toronto: University of Toronto Press, London: Routledge and Kegan Paul, 1972), http://oll.libertyfund.org/groups/46 [dostęp: 24 III 2015 r.].

Thompson S. C., „On G. H. Lewes's Problems of Life and Mind, 1874-1879”. BRANCH: Britain, Representation and Nineteenth-Century History. Ed. Dino Franco Felluga. Extension of Romanticism and Victorianism on the Net. Web. [dostęp:19 III 2019 r.].

\section{Opracowania:}

Ablowitz R., The theory of emergence, „Philosophy of Science” 6 (1939), nr 1, s. $1-16$.

Ashton R., 142 Strand: A Radical Address in Victorian London, London 2006.

Blitz D., Emergent evolution: Qualitative novelty and the levels of reality, Dordrecht 1992.

Capaldi N., John Stuart Mill. A Biography, New York 2004.

Haldane J., The Mystery of Emergence, „Proceedings of the Aristotelian Society” 96 (1996), s. 261-268.

Lewes G. H., Problems of Life and Mind: First Series: The Foundations of a Creed, t. 2, Boston 1875.

Lewes G. H., Problems of Life and Mind: Third Series: The Study of Psychology, t. 1, London 1879.

Maurer A. A., Rozdział XVII. Filozofia ewolucji, przeł. B. Chwedeńczuk, w:, Historia Filozofii Wspótczesnej, red. E. Gilson, T. Langan, A. A. Maurer, Warszawa 1977. 
Mazlish B., James and John Staurt Mill. Father and Son in the Nineteenth Century, New York 1975.

McLaughlin B. P., The Rise and Fall of British Emergentism, w: Emergence or Reduction? Essays on the Prospects of Nonreductive Physicalism, red. A. Beckermann, H. Flohr, J. Kim, Berlin 1992.

Meizner K., Poznawanie złożoności. Obliczeniowa dynamika materii, umystu i ludzkości, tłum. M. Hetmański, Lublin 2007.

Morgan C. L., Emergent Evolution, London 1923.

Oramus D., Darwinowskie paradygmaty. Mit teorii ewolucji w kulturze wspótczesnej, Kraków 2015.

Postlethwaite D., Making It Whole. A Victorian Circle and the Shape of Their World, Columbus 1984.

Spencer H., Autobiography, t. 2, London 1904.

Stephan A., Emergence - A Systematic View on its Historical Facets, w: Emergence or Reduction? Essays on the Prospects of Nonreductive Physicalism, red. A. Beckermann, H. Flohr, J. Kim, Berlin 1992.

Tjoa H. G., George Henry Lewes: A Victorian Mind, Cambridge 1977.

\section{Streszczenie}

W XIX wieku teoria ewolucji nie była jeszcze powszechnie przyjmowana i dopiero upowszechniała się w środowisku naukowym, a tym samym i wśród brytyjskich emergentystów. Pierwszymi przedstawicielami nurtu emergentyzmu brytyjskiego są John Stuart Mill oraz George Henry Lewes. Mill uważany jest za ojca tego kierunku, a Lewesowi zawdzięcza się ukucie terminu emergentny na określenie, tego, co Mill nazywał skutkiem heteropatycznym. Celem tego artykułu jest ukazanie odmiennego podejścia Milla i Lewesa do teorii ewolucji, a tym samym do emergentyzmu.

Słowa klucze: emergentyzm, teoria emergencji, teoria ewolucja, John Stuart Mill, George Henry Lewes, Charles Robert Darwin

\section{The First British Emergentist Attitude to Theory of Evolution}

\section{Summary}

In the nineteenth century, the theory of evolution was not yet widely accepted and was just beginning to spread in the scientific community, and thus also among British emergentists. The first representatives of British Emergentism were John Stuart Mill and George Henry Lewes. Mill is called the father of this line of thought, and 
Lewes coined the term emergent based on Mill's heteropathic effect. The purpose of this article is to show the different approaches of Mill and Lewes to the theory of evolution.

Key words: Emergentism, theory of emergence, theory of evolution, John Stuart Mill, George Henry Lewes, Charles Robert Darwin 